\title{
Plant growth-promoting rhizobacteria used in South Korea
}

\author{
Jerald Conrad Ibal ${ }^{1} \cdot$ Byung Kwon Jung ${ }^{1}$ - Chang Eon Park ${ }^{1}$. \\ Jae-Ho Shin ${ }^{1}$ (I)
}

Received: 12 September 2018/Accepted: 11 October 2018/Published online: 17 October 2018

(C) The Korean Society for Applied Biological Chemistry 2018

\begin{abstract}
Many bacteria found in the rhizosphere provide contribution for the host plant's growth and protection that are known as plant growth-promoting rhizobacteria (PGPR). Plant-microbe interactions in the rhizosphere are important factors in determining the health of plants. Research for commercialization of these PGPR as an alternative to the use of chemical fertilizers for a more environmentally friendly treatment is continuously being improved. In this review, we discuss the essential traits that rhizobacteria must possess for them to be considered PGPR and report the bacterial species that exhibit these essential plant growth-promoting activities and which are approved for use by the South Korean regulations.
\end{abstract}

Keywords Biocontrol - Ethylene synthesis - Nitrogen fixation - Phosphate solubilization · Phytohormones - Plant growth-promoting rhizobacteria (PGPR) in South Korea · Siderophore

\section{Introduction}

One of the great challenges currently under consideration is to developing environmentally wide-ranging and sustainable crop production methods. Crop production must be increased to provide food for the increasing population. Although the use of chemical fertilizers is a viable option, there are health risks associated when their improper use and these agents can cause environmental destruction.

\section{Jae-Ho Shin}

jhshin@knu.ac.kr

1 School of Applied Biosciences, Kyungpook National University, Daegu, Republic of Korea
Plant biotechnology has provided insight and aided the development of new crops to overcome complications caused by abiotic stresses (soil salinization and sodification, drought, soil $\mathrm{pH}$, and temperature) and biotic factors such as pathogenicity by other living organisms, including bacteria, viruses, fungi, and parasites [1,2].

In plant-microbe interactions, which have been widely examined, the host plant and bacteria present along the rhizosphere exhibit intimate interactions. These interactions promote host plant growth and pathogen suppression. The rhizosphere is a well-characterized ecological niche affected by root exudates [3]. Bacteria with direct and indirect positive effects on the growth and health of the plant are known as plant growth-promoting rhizobacteria (PGPR). In this review, we describe various important properties required by bacterial species to be considered PGPR and report various bacterial species exhibiting PGP qualities in South Korea.

\section{Phytohormone production}

Most distinguished phytohormones are consisted of cytokinins, auxins, gibberellins, ethylene, and abscisic acid, and PGPR show potential for the production of these hormones. These phytohormones can facilitate processes such as plant cell enlargement, division, and extension of symbiotic and non-symbiotic roots $[1,4,5]$. Furthermore, plant-associated bacteria may influence the hormonal balance of a plant.

Indole acetic acid (IAA), also known as auxin, governs different stages of plant growth and development, namely cell division, cell elongation, and tissue differentiation, and assists in apical dominance. IAA produced by rhizobacteria affects the root system through the increase of weight and 
size, the number of branches, and the surface area in contact with the soil.

Similarly, plant responses to cytokinin application include enhanced cell division, enhanced root development, enhanced root hair formation, inhibited root elongation, shoot initiation, and other physiological responses. Gibberellins, in contrast, are a group of phytohormones that affects developmental strategies in higher plants and include stem elongation, seed germination, flowering, and fruit setting [6, 7].

\section{Ethylene synthesis inhibition}

Ethylene is another growth regulator that affects physiological processes in plants. It is related primarily to the plant's growth and defense systems which are triggered by stress responses. Factors such as light, temperature, salinity, pathogen attacks, and nutritional status alter ethylene levels. Moreover, ethylene also facilitates additional processes not related to stress such as ripening, root elongation, and seed development. As ethylene levels decrease, root system growth increases, as described above. Degradation of 1-aminocyclopropane-1-carboxylic acid (ACC), a direct precursor of ethylene, creates a concentration gradient that favors its exudation. Maintaining a balance between the ethylene and auxin is important since the two are related growth regulators, some effects attributed to auxin-producing bacteria result from ACC degradation $[1,8]$.

\section{Free nitrogen fixation}

Nitrogen is a key component in the synthesis of cellular enzymes, proteins, chlorophyll, DNA, and RNA, and, as a result, it is important in plant growth. Bacterial strains capable of nitrogen fixation are divided into two categories: root/legume-associated symbiotic bacteria and free nitrogen-fixing bacteria. The former specifically infect the roots to produce nodules, while the latter are non-specific and can form symbiotic relationships with other plants and organisms $[1,9]$.

\section{Phosphate solubilization}

Phosphorus is the second most important mineral nutrient after nitrogen limiting plant growth. Although soils contain a high concentration of total phosphorus, the amount available for plant uptake is limited because $\mathrm{P}$ is in an insoluble form. Bacteria present in the rhizosphere can solubilize phosphate through different mechanisms. The most common method of solubilizing phosphorus is by secreting organic acids that act as chelators. Solubilization of $\mathrm{P}$ in the rhizosphere is the most common mode of action that increases the availability of nutrients for host plant uptake [10].

\section{Production of siderophore}

Another essential plant nutrient is iron. Iron serves as a cofactor for numerous enzymes that are important in physiological processes such as photosynthesis, nitrogen fixation, and respiration. Similar to phosphorus, iron is abundant in the soil but is not available for plant uptake because $\mathrm{Fe}^{3+}$ predominates and reacts to form insoluble hydroxides. In a similar manner to solubilizing phosphates, bacteria present in the rhizosphere release organic compounds for chelation. A different strategy involves absorbing the iron-organic compound complex, where the iron is reduced in the plant and directly assimilated [11].

\section{Enzyme synthesis that hydrolyzes fungal cell walls}

PGPR may be applicable in agriculture for the biocontrol of plant pathogens. Production of cell wall-degrading enzymes plays a very important role in controlling pathogens. Cell wall-degrading enzymes including chitinase, $\beta$ 1,3-glucanase, cellulase, and protease that are secreted by PGPR directly inhibit the hyphal growth of fungal pathogens through the degradation of their cell which may be an alternative method for replacing chemical fungicides $[2,10,12]$.

\section{PGPR species in South Korea}

South Korea is one of the top countries leading research and development for biotechnology. Development of PGPR is one focus of this field. The South Korean government approved the use of 108 total species of bacteria, yeast, and fungi as fertilizers and some species as feeds. However, there was some misunderstanding because of changes in taxonomy and some isolates were found to be the same species. In the present study, only 51 bacterial species have been identified to have strains included in the Korean Agricultural Culture Collection (KACC). Among these, 40 were found to have PGP activities in previous studies (Table 1), while the 11 species require further examination. Additional research is needed to evaluate the PGP characteristics of these 11 species (Table 2).

\section{Conclusion}

The PGP activities of rhizosphere bacteria show great promise for applications in sustainable and ecofriendly agriculture. PGPR not only promote growth by providing nutrients but are also useful as biocontrol agents to protect 


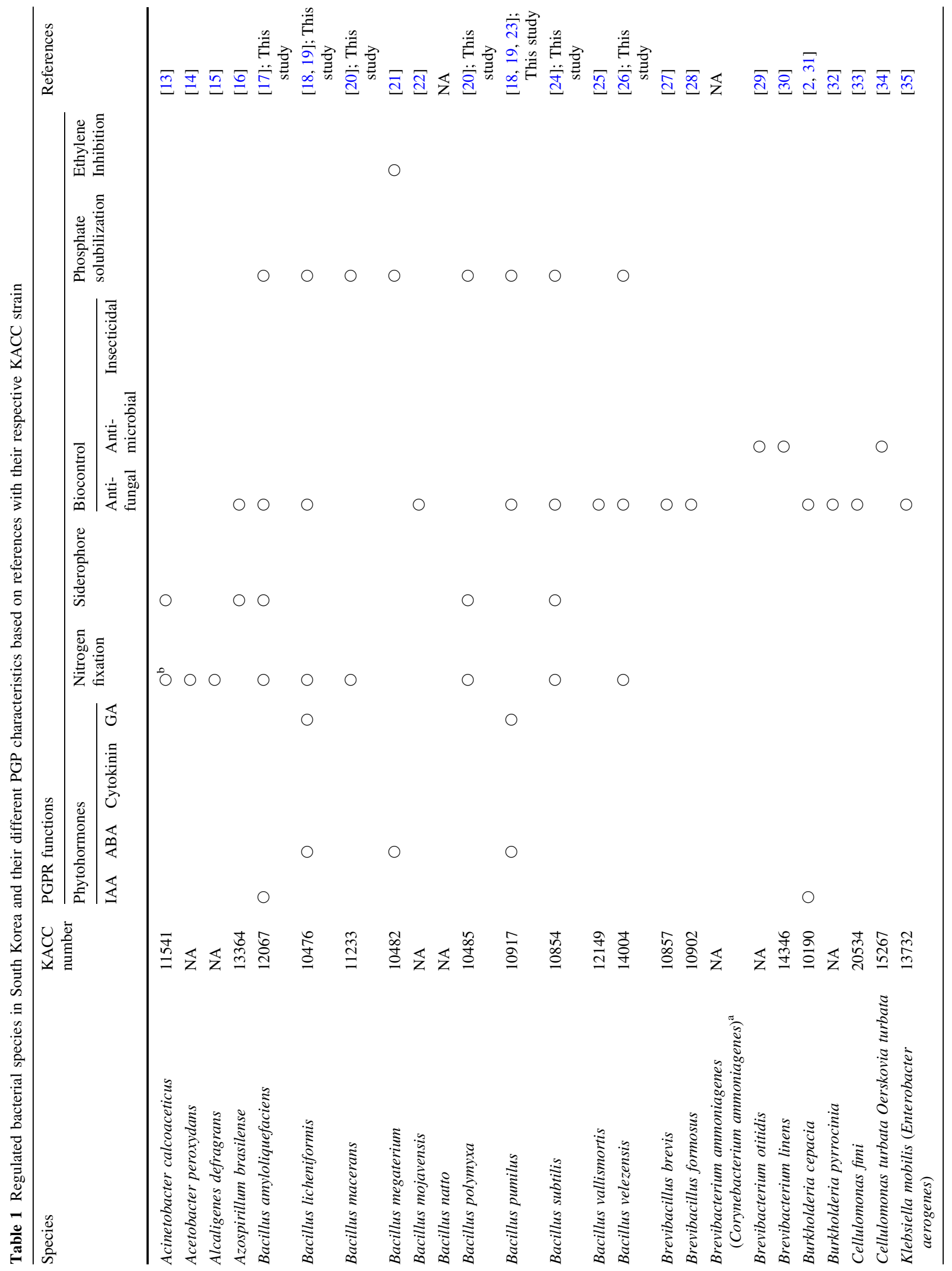




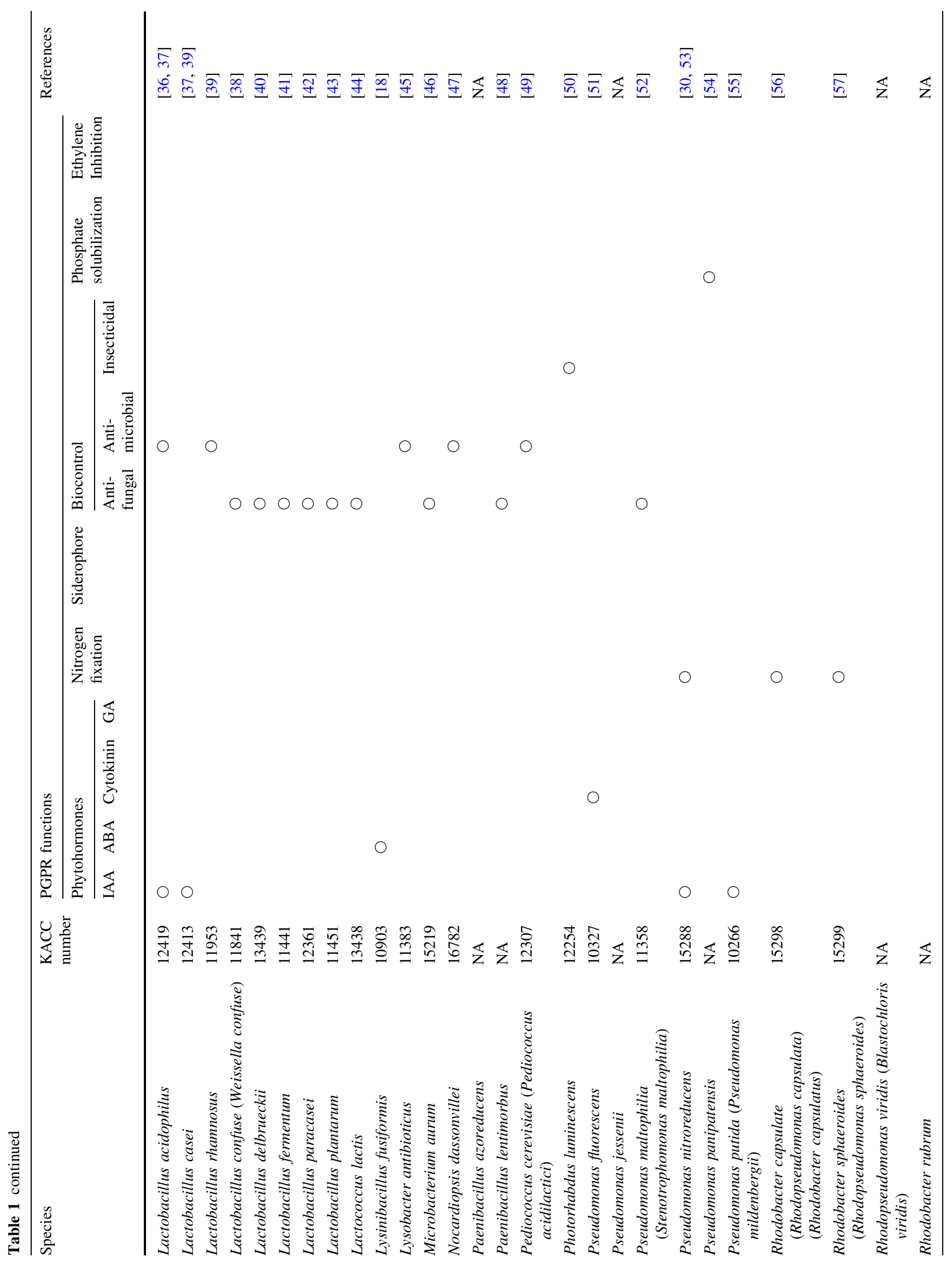




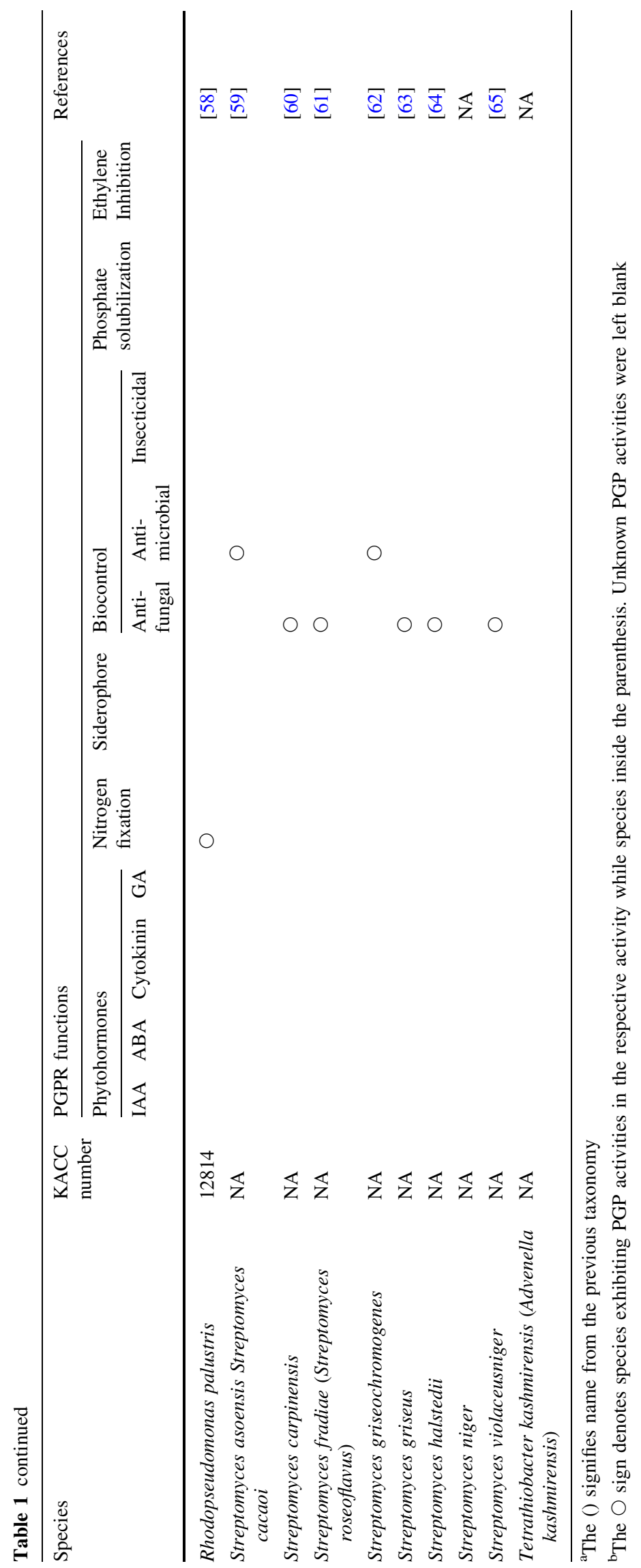


Table 2 Regulated bacterial species in South Korea and their KACC strains without reference for PGP qualities

\begin{tabular}{|c|c|c|}
\hline Species & KACC strain & PGPR function \\
\hline Paenibacillus amylolyticus & 11263 & Unknown \\
\hline Paenibacillus chibensis & 11242 & Unknown \\
\hline Paenibacillus chibensis & 11526 & Unknown \\
\hline Brevibacterium flavum $\left(\right.$ Corynebacterium glutamicum) ${ }^{\mathrm{a}}$ & 20786 & Unknown \\
\hline Frateuria aurantia & 11384 & Unknown \\
\hline Lactobacillus bulgaricus & 12420 & Unknown \\
\hline Lysinibacillus boronitolerans & 15323 & Unknown \\
\hline Pediococcus halophilus Tetragenococcus halophilus & 12355 & Unknown \\
\hline Pseudomonas nitroreducens & 15288 & Unknown \\
\hline Rhodobacter azotoformans & 14390 & Unknown \\
\hline Streptococcus cremoris (Lactococcus lactis cremoris) (Streptococcus lactis) & 13438 & Unknown \\
\hline Streptococcus thermophilus (Streptococcus salivarius subsp. thermophiles) & 11857 & Unknown \\
\hline
\end{tabular}

${ }^{a}$ Species inside the parenthesis () signifies name from the previous taxonomy

plants from pathogens. While the fundamentals of how PGPR promote growth are well known, there is still much more to learn about the mechanisms underlying plant-microbe interactions for commercial production for the microbes as an alternative to chemical fertilizers.

Acknowledgments This work was carried out with the support of "Cooperative Research Program for Agriculture Science and Technology Development (Project No. PJ013383)” Rural Development Administration, Republic of Korea.

\section{References}

1. Glick BR (2014) Bacteria with ACC deaminase can promote plant growth and help to feed the world. Mirobiol Res 169:30-39

2. Jung BK, Hong SJ, Park GS, Kim MC, Shin JH (2018) Isolation of Burkholderia cepacia JBK9 with plant growth-promoting activity while producing pyrrolnitrin antagonistic to plant fungal diseases. Appl Biol Chem 61:173-180

3. Berg G (2009) Plant-microbe interactions promoting plant growth and health: perspectives for controlled u se of microorganisms in agriculture. Appl Microbiol Biotechnol 84:11-18

4. Arshad M, Frankenberger WT Jr (1997) Plant growth-regulating substances in the rhizosphere: microbial production and functions. Adv Agron 62:45-151

5. Patten CL, Glick BR (1996) Bacterial biosynthesis of indole-3acetic acid. Can J Microbiol 42:207-220

6. Tsavkelova EA, Klimova SY, Cherdyntseva TA, Netrusov AI (2006) Microbial producers of plant growth stimulators and their practical use: a review. Appl Biochem Microbiol 42:117-126

7. Forghani AH, Almodares A, Ehsanpour AA (2018) Potential objectives for gibberellic acid and paclobutrazol under salt stress in sweet sorghum (Sorghum bicolor [L.] Moench cv. Sofra). Appl Biol Chem 61:113-124

8. Ali S, Khan MA, Kim WC (2018) Pseudomonas veronii KJ mitigates flood stress-associated damage in Sesamum indicum L. Appl Biol Chem 61:575-585

9. Oberson A, Frossard E, Buehlmann C, Mayer J, Maeder P, Luescher A (2013) Nitrogen fixation and transfer in grass-clover leys under organic and conventional cropping systems. Plant Soil 371:237-255

10. Vessey JK (2003) Plant growth promoting rhizobacteria as biofertilizers. Plant Soil 255:571-586

11. Payne SM (1994) Detection, isolation, and characterization of siderophores. Methods Enzymol 235:329-344

12. Hwang EJ, Lee YS, Choi YL (2018) Cloning, purification, and characterization of the organic solvent tolerant $\beta$-glucosidase, OaBGL84, from Olleya aquimaris DAU311. Appl Biol Chem $61: 1-12$

13. Chaudhari Bhushan L, Chincholkar Sudhir B, Rane Makarand R, Sarode Prashant D (2009) Siderophoregenic Acinetobacter calcoaceticus isolated from wheat rhizosphere with strong PGPR activity. Malays J Microbiol 5:6-12

14. Muthukumarasamy R, Cleenwerck I, Revathi G, Vadivelu M, Janssens D, Hoste B, Kang UG, Park KD, Son CY, Sa T, Caballero-Mellado J (2005) Natural association of Gluconacetobacter diazotrophicus and diazotrophic Acetobacter peroxydans with wetland rice. Syst Appl Microbiol 28:277-286

15. Flores A, Nisola GM, Cho E, Gwon EM, Kim H, Lee C, Park S, Chung WJ (2007) Bioaugmented sulfur-oxidizing denitrification system with Alcaligenes defragrans B21 for high nitrate containing wastewater treatment. Bioproc Biosyst Eng 30:197-205

16. Tortora ML, Díaz-Ricci JC, Pedraza RO (2011) Azospirillum brasilense siderophores with antifungal activity against $\mathrm{Col}$ letotrichum acutatum. Arch Microbiol 193:275-286

17. Yuan J, Ruan Y, Wang B, Zhang J, Waseem R, Huang Q, Shen Q (2013) Plant growth-promoting rhizobacteria strain Bacillus amyloliquefaciens NJN-6-enriched bio-organic fertilizer suppressed Fusarium wilt and promoted the growth of banana plants. J Agric Food Chem 61:3774-3780

18. Gutiérrez-Mañero FJ, Ramos-Solano B, Mehouachi J, Tadeo FR, Talon M (2001) The plant-growth-promoting rhizobacteria Bacillus pumilus and Bacillus licheniformis produce high amounts of physiologically active gibberellins. Physiol Plant 111:206-211

19. Belimov AA, Dodd IC, Safronova VI, Dumova VA, Shaposhnikov AI, Ladatko AG, Davies WJ (2014) Abscisic acid metabolizing rhizobacteria decrease $\mathrm{ABA}$ concentrations in planta and alter plant growth. Plant Physiol Biochem 74:84-91

20. Seldin L, Dubnau D (1985) Deoxyribonucleic acid homology among Bacillus polymyxa, Bacillus macerans, Bacillus 
azotofixans, and other nitrogen-fixing Bacillus strains. Int J Syst Evol Microbiol 35:151-154

21. Porcel R, Zamarreño ÁM, García-Mina JM, Aroca R (2014) Involvement of plant endogenous ABA in Bacillus megaterium PGPR activity in tomato plants. BMC Plant Biol 14:36

22. Bacon CW, Hinton DM (2002) Endophytic and biological control potential of Bacillus mojavensis and related species. Biol Control 23:74-284

23. Recep K, Fikrettin S, Erkol D, Cafer E (2009) Biological control of the potato dry rot caused by Fusarium species using PGPR strains. Biol Control 50:194-198

24. Kim BJ, Jung HK, Jeong YS, Yang SJ, Hong JH (2016) Effect of microencapsulated Bacillus subtilis strain CBD2-fermented grain on loperamide-induced constipation in mice. Appl Biol Chem 59:451-462

25. Zhao Z, Wang Q, Wang K, Brian K, Liu C, Gu Y (2010) Study of the antifungal activity of Bacillus vallismortis ZZ185 in vitro and identification of its antifungal components. Bioresour Technol 101:292-297

26. Nam MH, Park MS, Kim HG, Yoo SJ (2009) Biological control of strawberry Fusarium wilt caused by Fusarium oxysporum f. sp. fragariae using Bacillus velezensis BS87 and RK1 formulation. J Microbiol Biotechnol 19:520-524

27. Edwards SG, Seddon B (2001) Mode of antagonism of Brevibacillus brevis against Botrytis cinerea in vitro. J Appl Microbiol 91:652-659

28. Meena S, Gothwal RK, Mohan MK, Ghosh P (2014) Production and purification of a hyperthermostable chitinase from Brevibacillus formosus BISR-1 isolated from the Great Indian Desert soils. Extremophiles 18:451-462

29. Lobna M, Zawam H (2010) Efficacy of some biocontrol agents on reproduction and development of Meloidogyne incognita infecting tomato. J Am Sci 6:495-509

30. Motta AS, Brandelli A (2002) Characterization of an antibacterial peptide produced by Brevibacterium linens. J Appl Microbiol 92:63-70

31. Halda-Alija L (2003) Identification of indole-3-acetic acid producing freshwater wetland rhizosphere bacteria associated with Juncus effusus L. Can J Microbiol 49:781-787

32. Ren JH, Ye JR, Liu H, Xu XL, Wu XQ (2011) Isolation and characterization of a new Burkholderia pyrrocinia strain JKSH007 as a potential biocontrol agent. World J Microbiol Biotechnol 27:2203-2215

33. Martinez C, Michaud M, Belanger RR, Tweddell RJ (2002) Identification of soils suppressive against Helminthosporium solani, the causal agent of potato silver scurf. Soil Biol Biochem 34:1861-1868

34. Zhao K, Penttinen P, Chen Q, Guan T, Lindström K, Ao X, Zhang L, Zhang X (2012) The rhizospheres of traditional medicinal plants in Panxi, China, host a diverse selection of actinobacteria with antimicrobial properties. Appl Microbiol Biotechnol 94:1321-1335

35. Cottyn B, Debode J, Regalado E, Mew TW, Swings J (2009) Phenotypic and genetic diversity of rice seed-associated bacteria and their role in pathogenicity and biological control. J Appl Microbiol 107:885-897

36. Al-Dohail MA, Hashim R, Aliyu-Paiko M (2011) Evaluating the use of Lactobacillus acidophilus as a biocontrol agent against common pathogenic bacteria and the effects on the haematology parameters and histopathology in African catfish Clarias gariepinus juveniles. Aquac Res 42:196-209

37. Mohite B (2013) Isolation and characterization of indole acetic acid (IAA) producing bacteria from rhizospheric soil and its effect on plant growth. J Soil Sci Plant Nutr 13:638-649
38. Oliveira PM, Zannini E, Arendt EK (2014) Cereal fungal infection, mycotoxins, and lactic acid bacteria mediated bioprotection: from crop farming to cereal products. Food Microbiol 37:78-95

39. De Keersmaecker SC, Verhoeven TL, Desair J, Marchal K, Vanderleyden J, Nagy I (2006) Strong antimicrobial activity of Lactobacillus rhamnosus GG against Salmonella typhimurium is due to accumulation of lactic acid. FEMS Microbiol Lett 259:89-96

40. Voulgari K, Hatzikamari M, Delepoglou A, Georgakopoulos P, Litopoulou-Tzanetaki E, Tzanetakis N (2010) Antifungal activity of non-starter lactic acid bacteria isolates from dairy products. Food Control 21:136-142

41. Gerez CL, Torres MJ, De Valdez GF, Rollán G (2013) Control of spoilage fungi by lactic acid bacteria. Biol Control 64:231-237

42. Hassan YI, Bullerman LB (2008) Antifungal activity of Lactobacillus paracasei $\mathrm{ssp}$. tolerans isolated from a sourdough bread culture. Int J Food Microbiol 121:112-115

43. Mejri L, Hassouna M (2016) Characterization and selection of Lactobacillus plantarum species isolated from dry fermented sausage reformulated with camel meat and hump fat. Appl Biol Chem 59:533-542

44. Roy U, Batish VK, Grover S, Neelakantan S (1996) Production of antifungal substance by Lactococcus lactis subsp. lactis CHD28.3. Int J Food Microbiol 32:27-34

45. Ji GH, Wei LF, He YQ, Wu YP, Bai XH (2008) Biological control of rice bacterial blight by Lysobacter antibioticus strain 13-1. Biol Control 45:288-296

46. Fang LZ, Kun XC, Song ZC, Qin XJ, Qiu HY, Qun DC, He MM (2011) Fungistatic intensity of agricultural soil against fungal agents and phylogenetic analysis on the actinobacteria involved. Curr Microbiol 62:1152-1159

47. Vimal V, Rajan BM, Kannabiran K (2009) Antimicrobial activity of marine Actinomycete, Nocardiopsis sp. VITSVK 5 (FJ973467). Asian J Med Sci 1:57-63

48. Montealegre JR, Herrera R, Velásquez JC, Silva P, Besoaín X, Pérez LM (2005) Biocontrol of root and crown rot in tomatoes under greenhouse conditions using Trichoderma harzianum and Paenibacillus lentimorbus: Additional effect of solarization. Electron J Biotechnol 8:249-257

49. Bhunia AK, Johnson MC, Ray B (1988) Purification, characterization and antimicrobial spectrum of a bacteriocin produced by Pediococcus acidilactici. J Appl Bacteriol 65:261-268

50. Bowen D, Rocheleau TA, Blackburn M, Andreev O, Golubeva E, Bhartia R (1998) Insecticidal toxins from the bacterium Photorhabdus luminescens. Science 280:2129-2132

51. García de Salamone IE, Hynes RK, Nelson LM (2001) Cytokinin production by plant growth promoting rhizobacteria and selected mutants. Can J Microbiol 47:404-411

52. Zhang Z, Yuen GY, Sarath G, Penheiter AR (2001) Chitinases from the plant disease biocontrol agent, Stenotrophomonas maltophilia C3. Phytopathology 91:204-211

53. Dashti N, Ali N, Khanafer M, Al-Awadhi H, Sorkhoh N, Radwan S (2015) Olive-pomace harbors bacteria with the potential for hydrocarbon-biodegradation, nitrogen-fixation and mercury-resistance: promising material for waste-oil-bioremediation. J Environ Manag 155:49-57

54. Raj DPRS, Linda R, Babyson RS (2014) Molecular characterization of phosphate solubilizing bacteria (PSB) and plant growth promoting rhizobacteria (PGPR) from pristine soil. Int J Innov Sci Eng Technol 1:317-324

55. Xie H, Pasternak JJ, Glick BR (1996) Isolation and characterization of mutants of the plant growth-promoting rhizobacterium Pseudomonas putida GR12-2 that overproduce indoleacetic acid. Curr Microbiol 32:67-71

56. Elbadry M, Gamal-Eldin H, Elbanna K (1999) Effects of Rhodobacter capsulatus inoculation in combination with graded 
levels of nitrogen fertilizer on growth and yield of rice in pots and lysimeter experiments. World J Microb Biotechnol 15:393-395

57. Satoh T, Hoshino Y, Kitamura H (1976) Rhodopseudomonas sphaeroides forma sp. denitrificans, a denitrifying strain as a subspecies of Rhodopseudomonas sphaeroides. Arch Microbiol 108:265-269

58. Larimer FW, Chain P, Hauser L, Lamerdin J, Malfatti S, Do L, Land ML, Pelletier DA, Beatty JT, Lang AS, Gibson JL, Hanson TE, Bobst C, Torres JL, Peres C, Harrison FH, Gibson J, Tabita FR, Harwood CS (2004) Complete genome sequence of the metabolically versatile photosynthetic bacterium Rhodopseudomonas palustris. Nat Biotechnol 22:55

59. Kobayashi YO, Kobayashi A, Maeda M, Someya N, Takenaka S (2015) Biological control of potato scab and antibiosis by antagonistic Streptomyces sp. WoRs-501. J Gen Plant Pathol $81: 439-448$

60. Jog R, Nareshkumar G, Rajkumar S (2012) Plant growth promoting potential and soil enzyme production of the most abundant Streptomyces spp. from wheat rhizosphere. J Appl Microbiol 113:1154-1164

61. Swart EA, Romano AH, Waksman SA (1950) Fradicin, an antifungal agent produced by Streptomyces fradiae. Proc Soc Exp Biol Med 73:376-378

62. Montesinos E (2007) Antimicrobial peptides and plant disease control. FEMS Microbiol Lett 270:1-11

63. Itoh $\mathrm{Y}$, Takahashi $\mathrm{K}$, Takizawa $\mathrm{H}$, Nikaidou $\mathrm{N}$, Tanaka $\mathrm{H}$, Nishihashi H, Watanabe T, Nishizawa Y (2003) Family 19 chitinase of Streptomyces griseus HUT6037 increases plant resistance to the fungal disease. Biosci Biotechnol Biochem $67: 847-855$

64. Joo GJ (2005) Purification and characterization of an extracellular chitinase from the antifungal biocontrol agent Streptomyces halstedii. Biotechnol Lett 27:1483-1486

65. Shekhar N, Bhattacharya D, Kumar D, Gupta RK (2006) Biocontrol of wood-rotting fungi with Streptomyces violaceusniger XL-2. Can J Microbiol 52:805-808 